\title{
Detection of cytotoxic necrotising factor (CNF) in extracts of Escherichia coli strains by enzyme-linked immunosorbent assay
}

\author{
M. TABOURET and J. DE RYCKE
}

\begin{abstract}
Institut National de la Recherche Agronomique, Station de Pathologie de la Reproduction, 37380 Nouzilly, France
\end{abstract}

\begin{abstract}
Summary. An enzyme-linked immunosorbent assay (ELISA) consisting of a double sandwich technique with rabbit and sheep antibodies, was developed for the detection of cytotoxic necrotising factor (CNF) in extracts of Escherichia coli strains. The assay was evaluated by comparison with the results obtained with an assay based on toxicity for HeLa cell cultures. In a study of extracts of $27 \mathrm{CNF}^{+}$and $45 \mathrm{CNF}^{-}$strains obtained by ultrasonic disintegration, no false positive and only three false negative results were recorded; the latter were obtained with strains that produced less CNF than any of the others examined. Frozen-thawed extracts contained about four times more CNF cytotoxic activity than extracts prepared ultrasonically; the testing of 54 $\mathrm{CNF}^{+}$and $68 \mathrm{CNF}^{-}$frozen-thawed extracts resulted in no false positive and only one false negative response. Whichever type of extract was used, no significant crossreaction was observed with heat-labile (LT) or heat stable (ST) enterotoxin, verotoxin (VT1, VT2), haemolysin, or Vir cytotoxin.
\end{abstract}

\section{Introduction}

Cytotoxic necrotising factor (CNF) of Escherichia coli was first identified in extracts of isolates from cases of infant enteritis by Caprioli et al. ${ }^{1}$ This factor induced necrosis in rabbit skin and provoked the formation of giant, rounded, polynucleated cells in cultures of $\mathrm{HeLa}$, Vero and other cells. It was later purified ${ }^{2}$ and identified immunochemically with sodium dodecyl sulphate-polyacrylamide gel electrophoresis (SDS-PAGE) as a protein of $115 \mathrm{Kda}^{3}$ In addition to enteritis, CNF-producing strains were shown to be associated with extraintestinal infections in man, including septicaemia ${ }^{4}$ and urinary tract infection. ${ }^{5}$ CNF-producing strains have also been detected in piglet and calf enteritis. $^{6-9}$ Most CNF-producing strains were haemolytic, but CNF production and haemolytic activity were shown to be dissociated. ${ }^{1,3}$ CNFproducing strains did not exert enterotoxic activity in the rabbit ileal loop test. ${ }^{1}$

More recently, a second toxic factor causing multinucleation in HeLa cell culture and necrosis in rabbit skin was discovered in $E$. coli strains isolated from calves and lambs with enteritis. ${ }^{7,8}$ This toxin (Vir cytotoxin ${ }^{11}$ ) was encoded by the Vir plasmid of $E$. coli ${ }^{10}$ and was present in all presumed

Received 31 July 1989; accepted 10 Oct. 1989.
Vir strains previously described. ${ }^{11}$ The cytopathic effect of Vir cytotoxin in HeLa cell culture assay was morphologically distinguishable from that caused by CNF. ${ }^{7,11}$ Cross-neutralisation tests revealed an antigenic relationship between $\mathrm{Vir}$ cytotoxin and $\mathrm{CNF}$. ${ }^{7,11}$

CNF-producing $E$. coli strains have been isolated from severe pathological processes in man and animals, but their actual role in disease has not yet been elucidated. Therefore, a systematic search for CNF-producing strains in well-defined pathological conditions is needed. The cytotoxicity assay is at present performed in very few laboratories, probably because (a) it requires the use of tissue culture, (b) the response in cell culture assay is obtained only after incubation for $72 \mathrm{~h}$, and (c) the toxin is sought in sonicated extracts whose production necessitates manipulation of each bacterial culture. To eliminate these drawbacks and hence facilitate the large scale detection of CNF-producing strains, this report describes an enzyme-linked immunosorbent assay (ELISA) with neutralising polyclonal antibodies produced in rabbits and sheep.

\section{Materials and methods}

\section{E. coli strains}

Details of the $E$. coli strains and of the tests in which they were used are shown in table I. Seventy-two strains, 
Table I. $E$. coli strains tested in the ELISA

\begin{tabular}{|c|c|c|c|c|}
\hline \multirow{2}{*}{$\begin{array}{l}\text { Toxic properties } \\
\text { of strains }\end{array}$} & \multirow[b]{2}{*}{ Toxin produced } & \multirow[b]{2}{*}{ Origin of strains } & \multicolumn{2}{|c|}{ Number of strains tested as } \\
\hline & & & sonicated extracts & frozen-thawed extracts \\
\hline \multirow[t]{9}{*}{ Cytotoxic } & CNF & Man & 5 & 16 \\
\hline & & Pig & 3 & 4 \\
\hline & & Cow & 19 & 34 \\
\hline & Vir & Sheep & 2 & 2 \\
\hline & & Cow & 6 & 10 \\
\hline & VT & Man & 0 & 2 \\
\hline & & Pig & 0 & 4 \\
\hline & & Cow & 6 & 6 \\
\hline & & Rabbit & 0 & 1 \\
\hline \multirow[t]{3}{*}{ Enterotoxic } & ST & Cow & 5 & 5 \\
\hline & LT & Man & 0 & 3 \\
\hline & & Pig & 2 & 6 \\
\hline \multirow[t]{3}{*}{ Haemolytic only } & & Man & 0 & 13 \\
\hline & & Pig & 1 & 0 \\
\hline & & Cow & 2 & 1 \\
\hline \multirow{2}{*}{ None } & & Man & 0 & 2 \\
\hline & & Cow & 21 & 13 \\
\hline
\end{tabular}

including $27 \mathrm{CNF}$-producing $\left(\mathrm{CNF}^{+}\right)$strains, were assayed as sonicated extracts and a larger group of 122 strains, including $54 \mathrm{CNF}^{+}$strains, were tested as frozenthawed extracts. The detection of cytotoxicity (CNF, Vir cytotoxin, VT) was performed in HeLa and Vero cellculture assays and confirmed by seroneutralisation studies with specific rabbit antisera against CNF, Vir cytotoxin and VT as described previously. ${ }^{7}$

Most $\mathrm{CNF}^{+}$strains were isolated from the faeces of human patients or animals with diarrhoea (41 strains); a few came from extra-intestinal sites: blood (10 strains), kidney (one strain), lung (one strain) and mammary gland (one strain). The strains belonged to a limited number of $\mathrm{O}$ groups, particularly $\mathrm{O} 2, \mathrm{O} 4, \mathrm{O}, \mathrm{O}, \mathrm{O}, \mathrm{O11}, \mathrm{O} 15, \mathrm{O} 23$ and 075 . Except for the animal strains that had been isolated at this laboratory, all CNF strains were kindly provided by the following investigators: A. Caprioli, Instituto Superiore di Sanita, Roma, Italy (four strains); E. González, Facultad de Veterinaria, Lugo, Spain (eight strains); C. L. Gyles, University of Guelph, Ontario, Canada, (six strains); M. Contrepois, Laboratoire de Microbiologie, INRA CRVZ, Theix, France (31 strains).

\section{Production of bacterial extracts}

The bacterial strains were inoculated into 100 -ml flasks containing $10 \mathrm{ml}$ of Trypticase Soy Broth (TSB ; Biomérieux, Charbonnières-les-Bains, France). Cultures were incubated at $37^{\circ} \mathrm{C}$ for $24 \mathrm{~h}$ with shaking $(160 \mathrm{rpm})$ and then centrifuged at $10000 \mathrm{~g}$ for $20 \mathrm{~min}$. The resulting pellet was resuspended in $1 \mathrm{ml}$ of phosphate-buffered saline, pH 7.2 (PBS), containing penicillin G 100 units/ $\mathrm{ml}$ and streptomycin $1 \mu \mathrm{g} / \mathrm{ml}$. Extracts were produced from bacterial suspensions by subjecting them to (a) ultrasonic disruption (MSE ultrasonic disintegrator, Crawley) for $5 \mathrm{~min}$ at $4^{\circ} \mathrm{C}$, or (b) three freeze-thawing cycles from $37^{\circ} \mathrm{C}$ to $-20^{\circ} \mathrm{C}$. The lysates were then centrifuged $(10000 \mathrm{~g}, 15 \mathrm{~min})$ to remove intact cells and debris.

The protein concentration of the bacterial extracts was determined by the method of Bradford $;^{12}$ the Bio-Rad protein assay (Bio-Rad Laboratories, München, West Germany) was used, with bovine serum albumin as standard.

\section{Purification of CNF toxin}

CNF was purified from cell lysates of a bovine $E$. coli strain (BM2-1) as previously described, ${ }^{3}$ by means of the following successive steps: ammonium sulphate precipitation, DEAE Trisacryl M-ion-exchange chromatography, Sephacryl S 200 gel-filtration, and preparative nondenaturing gel electrophoresis. The purification procedure led to an overall increase of cytotoxic activity of about 1000 -fold. Crude sonicated extract contained $0 \cdot 8$ CD50 (50\% cytotoxic doses) $/ \mu \mathrm{g}$ of total protein and purified material $830 \mathrm{CD} 50 / \mu \mathrm{g}$.

\section{Cytotoxicity assay}

The measurement of CNF activity and of its specific seroneutralisation was performed with $\mathrm{HeLa}$ cell cultures according to the methods previously described. ${ }^{7}$ The CD50 was defined as the minimal amount of toxic preparation that produced at least $50 \%$ multinucleated cells after $72 \mathrm{~h}$ of incubation (two-fold dilutions were performed).

The neutralisation titre was defined as the highest dilution of antiserum or IgG preparation that neutralised at least $90 \%$ of the multinucleating effect produced by CNF. 


\section{Production of antisera}

Anti-CNF serum was obtained from New Zealand White rabbits as previously described. ${ }^{3}$ The first immunisation consisted of the intradermal injection of $1 \mathrm{mg}$ $\left(10^{3} \mathrm{CD} 50\right)$ of a crude extract of the $\mathrm{CNF}^{+}$strain $\mathrm{BM} 2-$ 1 , emulsified in an equal volume of Freund's complete adjuvant (Difco Laboratories, Detroit, MI, USA) at about 20 different dorsal sites. Five further immunisations were performed at 3-week intervals in the same manner except that Freund's incomplete adjuvant (Difco) was used. The immunisation procedure was well tolerated by the rabbits and no sign of discomfort was observed. The neutralisation titre of the serum collected one week after the final dose was 2560 .

Sheep CNF antiserum was obtained by six intramuscular injections, performed at 3-week intervals, of partly purified CNF extract (gel filtration material) from strain BM2-1; this was detoxified by prior incubation with formaldehyde $0.5 \%$ for 3 days at $37^{\circ} \mathrm{C}$. For the first immunisation, $4 \mathrm{mg}$ of protein $\left(2 \times 10^{5} \mathrm{CD} 50\right)$ in a volume of $4 \mathrm{ml}$ were mixed with an equal volume of Freund's complete adjuvant and inoculated intramuscularly on the inner aspect of each limb. The subsequent immunisations were performed similarly except that Freund's incomplete adjuvant was used for the second and no adjuvant for the remainder. The neutralisation titre of the serum collected 1 week after the final dose was 1280. Rabbit and sheep immune sera cross-neutralised the specific cytotoxic effect produced in HeLa cell cultures by Vir cytotoxin at titres of 40 and 20 respectively.

\section{Preparation of purified antibodies specific for $C N F$}

The immunoglobulin $\mathrm{G}$ (IgG) fraction of immune sera collected from rabbits and sheep was purified by the method of McKinney and Parkinson, ${ }^{13}$ based on the removal of contaminating protein by precipitation with caprylic acid and the collection of IgG by precipitation with $45 \%$ saturated ammonium sulphate.

To increase the specificity of the IgG preparations for CNF, an absorption procedure in two steps was used as described previously. ${ }^{3}$ Firstly each IgG preparation was adsorbed on washed live, then heat-killed $\left(100^{\circ} \mathrm{C}\right)$, cells of vaccinal strain BM2-1, to remove non-specific antibodies against surface antigens. The resulting preparation was then adsorbed on proteins extracted from a CNFdeficient mutant from BM2-1 (BM2-1-M1) whose isolation and characterisation have been published previously ${ }^{3}$ and immobilised on glutaraldehyde-activated polyacrylamide agarose beads of ACA 34 (LKB, Orsay, France), according to the method of Guesdon and Avrameas. ${ }^{14}$

After absorption, IgG preparations were dialysed against PBS and restored to the initial serum volume. The final neutralisation titres of rabbit and sheep IgG preparations were 320 and 160 for $\mathrm{CNF}$, and 10 and 5 for Vir cytotoxin respectively.

\section{ELISA technique}

A double sandwich technique was performed as follows: (a) coating of the solid phase with rabbit IgG; (b) capture of the bacterial extract to be tested; (c) detection with sheep IgG preparation; (d) amplification and demonstration with peroxidase-labelled rabbit antisheep immunoglobulins. Flat-bottomed polystyrene microtitre plates with 96 wells (Immunoplate 1, Nunc, Copenhagen, Denmark) were used as the solid phase and volumes of $100 \mu \mathrm{l}$ were used in each step of the procedure. Optimal dilutions of the various antisera used were determined by preliminary checkerboard titrations.

A 1 in 400 dilution $(0.75 \mu \mathrm{g}$ of protein $/ \mathrm{ml})$ in $0.1 \mathrm{M}$ carbonate-bicarbonate buffer ( $\mathrm{pH}$ 9.7) of the anti-CNF rabbit IgG preparation was incubated for $2 \mathrm{~h}$ at $37^{\circ} \mathrm{C}$ and then kept at $4^{\circ} \mathrm{C}$ until used. Plates could be stored for 2 months without loss of sensitivity. Wells were rinsed once with PBS containing Tween $200.05 \% \mathrm{v} / \mathrm{v}$ (PBS-T) and four times with distilled $\mathrm{H}_{2} \mathrm{O}$. Remaining binding sites were blocked by incubating wells with dehydrated milk (Regilait, France Lait, St Martin de Belleroche, France) $0.2 \% \mathrm{w} / \mathrm{v}$ in PBS for $1 \mathrm{~h}$ at $37^{\circ} \mathrm{C}$ and overnight at $4^{\circ} \mathrm{C}$, or $1.5 \mathrm{~h}$ at $37^{\circ} \mathrm{C}$. Plates were then washed three times with PBS-T. The washing was repeated after each step. Bacterial extracts diluted in PBS-T containing dehydrated milk $0.4 \% \mathrm{w} / \mathrm{v}$ (PBS-T-M), were added and plates were incubated for $1.5 \mathrm{~h}$ at $37^{\circ} \mathrm{C}$. The IgG fraction of sheep antiserum, diluted 1 in $320(4.30 \mu \mathrm{g}$ of protein/ $\mathrm{ml}$ ) in PBS-T-M, was then added and plates were incubated for $1.5 \mathrm{~h}$ at $37^{\circ} \mathrm{C}$. At this point, horseradish peroxidase-labelled rabbit anti-sheep immunoglobulin (Nordic Laboratories, Langestraat, The Netherlands), specific for both heavy and light chains, diluted 1 in 800 in PBS-T-M, was added to each well. Plates were again incubated for $1.5 \mathrm{~h}$ at $37^{\circ} \mathrm{C}$. The presence of enzyme was detected by incubation with substrate-2,2'-Azinobis(3ethylbenzothiazoline-6-sulphonic acid) diammonium salt (Sigma) $110 \mu \mathrm{g} / \mathrm{ml}$ and $\mathrm{H}_{2} \mathrm{O}_{2} 30 \% 4 \cdot 2 \mu \mathrm{l} / \mathrm{ml}$ diluted in citrate buffer $0.1 \mathrm{M}, \mathrm{pH} 4.0-$ for $20 \mathrm{~min}$ at $37^{\circ} \mathrm{C}$. The absorbance was read spectrophotometrically with a Titertek Multiskan apparatus (Flow Laboratories, Helsinki, Finland) at $414 \mathrm{~nm}$. An adjusted absorbance was determined for each well by subtracting the mean absorbance of three control wells in which bacterial extracts had been replaced by the dilution buffer PBS-TM.

Each sample was assayed in duplicate or triplicate. A positive/negative $(P / N)$ value was determined by dividing the adjusted absorbance of the sample by the absorbance produced by the control CNF-deficient mutant (BM2-1M1).

\section{Evaluation criteria}

The performance of the ELISA was evaluated with reference to the results obtained by HeLa cell culture assay. The following criteria, proposed by Tijssen, ${ }^{15}$ were used. (a) Specificity: the ability of ELISA to detect CNF as opposed to other molecular species present in extracts of $E$. coli strains. (b) Detectability index of positive strain $(\mathrm{DI}(+))$ : the percentage of positive results in $\mathrm{CNF}^{+}$ strains. (c) Detectability index of negative strains 
$(D I(-))$ : the percentage of negative results in strains not producing CNF. (d) Detection limit : the minimal amount of cytotoxin, in terms of number of CD50, producing a significant response in ELISA. (e) Sensitivity: the change in response produced by one CD50 within the linear part of the dose response curve. (f) Reproducibility: the standard deviation of the responses produced in several plates by the same sample.

\section{Results}

\section{Specificity of the ELISA for CNF}

The response of purified CNF in the ELISA was dose-dependent and linear from about 2.8 CD50 to at least $91 \cdot 1$ CD50 (fig. 1). Higher concentrations were not tested. The crude sonicated extract, from which CNF was purified, also produced a linear dose-dependent response between approximately 1.4 and 45.5 CD50. For the same quantity of CNF activity (as determined by the CD50) the optical density obtained with the crude extract was greater than with purified $\mathrm{CNF}$, the absorbance difference between the two curves being due to non-specific reactions (fig. 1). The specificity of ELISA was also assessed by comparing response curves obtained with sonicated extracts from the $\mathrm{CNF}^{+}$strain BM2-1 and its $\mathrm{CNF}^{-}$mutant (fig. 2). Within the tested protein dose range $(0.85$ to $108 \mu \mathrm{g} /$ well $)$ the

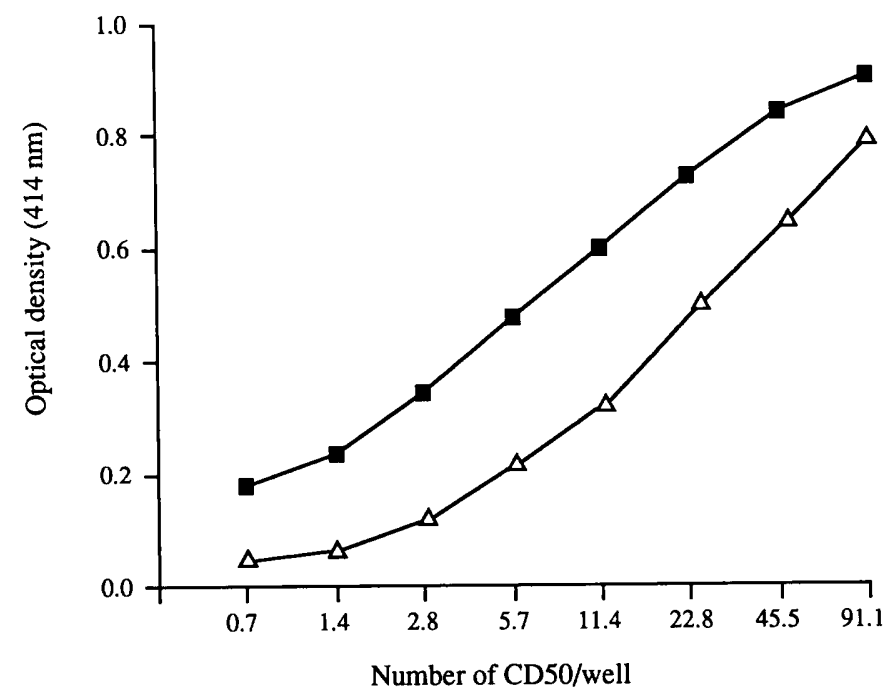

Fig. 1. Responses produced by purified CNF ( $\Delta-\Delta)$ and crude sonicated extract from $\mathrm{CNF}^{+}$strain $\mathrm{BM}_{2-1}(-\rightarrow-4)$ in the ELISA. One CD50 corresponded to about $1.2 \mathrm{ng}$ of protein from purified CNF and to about $1.2 \mu \mathrm{g}$ of protein from crude sonicated bacterial extract.

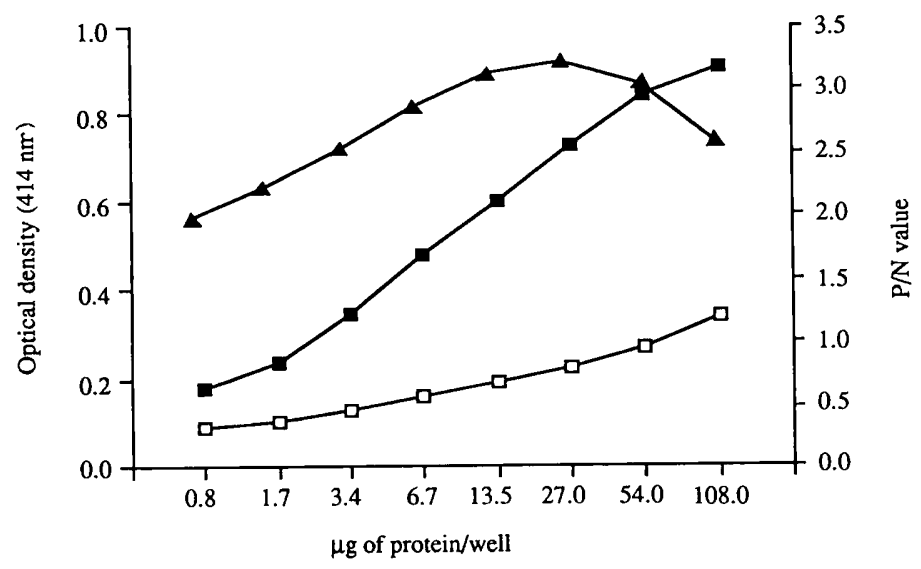

Fig. 2. Response produced by sonicated extracts from $\mathrm{CNF}^{+}$strain $\mathrm{BM} 2-1(-\rightarrow)$ ) and from its $\mathrm{CNF}^{-}$mutant $\mathrm{BM}^{-1-\mathrm{M}^{-}}$ $(\square-\square-\square)$ in the ELISA, and variation of the P/N value according to the amount of extract/well $(-\downarrow-1)$; BM2-1 extract contained about $0.74 \mathrm{CD} 50 / \mu \mathrm{g}$ of protein. 
absorbance produced by the $\mathrm{CNF}^{-}$mutant (i.e., the non-specific response), varied from 0.09 to 0.34 , whereas the one produced by BM2-1 varied from 0.18 to 0.90 . The maximal difference in absorbance produced by sonicated extracts was observed with a dose of about $27 \mu \mathrm{g}$ of protein/well. The corresponding ratio of absorbances ( $\mathrm{P} / \mathrm{N}$ value) was 3.3 .

\section{Evaluation of ELISA for the detection of $\mathrm{CNF}^{+}$ strains with sonicated extracts}

Because the optimal $\mathbf{P} / \mathbf{N}$ value was obtained with $27 \mu \mathrm{g}$ of sonicated extract from strain BM2-1, all strains were assayed with this dose. The range of $\mathbf{P} / \mathrm{N}$ values for $\mathrm{CNF}^{-}$strains fitted a normal distribution (test of goodness of fit; $5 \mathrm{df} ; \mathrm{p}>0.05$ ) (fig. 3). The cut-off point for positive value was determined as the mean of $P / N$ values of the $45 \mathrm{CNF}^{-}$strains in the cytotoxicity assay $(0.92)$ plus two standard deviations $(2 \times 0.29)$, i.e., 1.5 . According to this criterion, 24 of the $27 \mathrm{CNF}^{+}$ strains were positive in the ELISA, whereas all the $\mathrm{CNF}^{-}$strains were negative, including the eight that produced Vir cytotoxin. These figures provided a DI( +) of $89 \%$ and a DI $(-)$ of $100 \%$.

The three false negative responses in the ELISA were due to the lowest CNF-producers of the sample, i.e., Pomd B, 7d and 249 (fig. 4), containing $0.24,0.16$ and $0.06 \mathrm{CD} 50 / \mu \mathrm{g}$ of protein, respectively. The detection limit of the assay as applied to sonicated extracts can be estimated as about 0.25 CD50/ $\mu$ g, i.e., about 6.75 CD50/well. Overall, the ELISA and the cytotoxicity assay showed a highly significant correlation as determined by regression analysis $(r=0.98)$ (fig. 4).

The DI(+) of the assay could be improved by increasing the amount of protein/well (table II). In comparison to $27 \mu \mathrm{g}$, a dose of $108 \mu \mathrm{g}$ of protein/ well resulted in the following alterations in $P / N$ values: a decrease for high CNF-producers (BUV21, EB28), an increase for low CNF-producers (Pomd B, 7d, 249) and no significant change for $\mathrm{CNF}^{-}$strains (S5, B20a, B24c, B41). With the larger dose, the $\mathrm{P} / \mathrm{N}$ values of two of the three low CNF-producers previously classified as negative in ELISA became positive. This resulted in an increase of the DI(+) from $89 \%$ to $97 \%$.

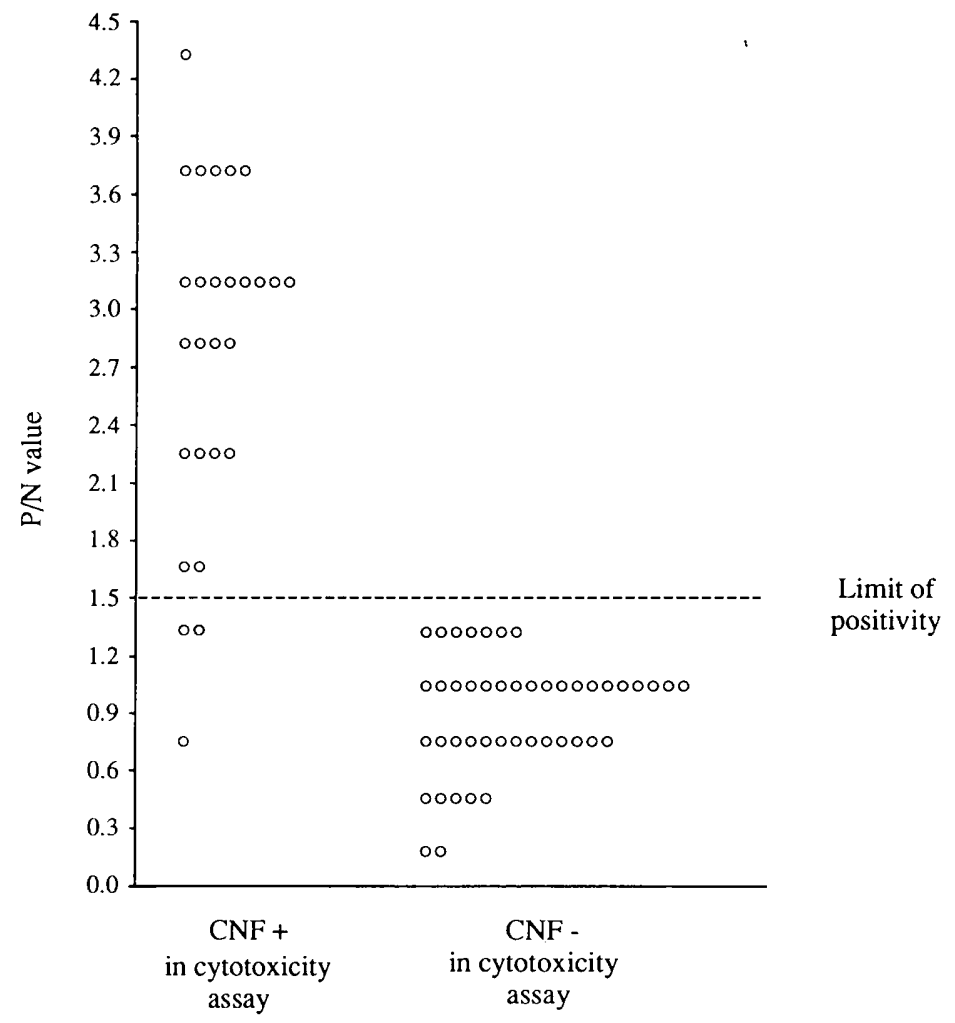

Fig. 3. Results of the ELISA with sonicated extracts from $27 \mathrm{CNF}^{+}$strains and $45 \mathrm{CNF}^{-}$strains with reference to cytotoxicity results in the HeLa cell culture assay. 


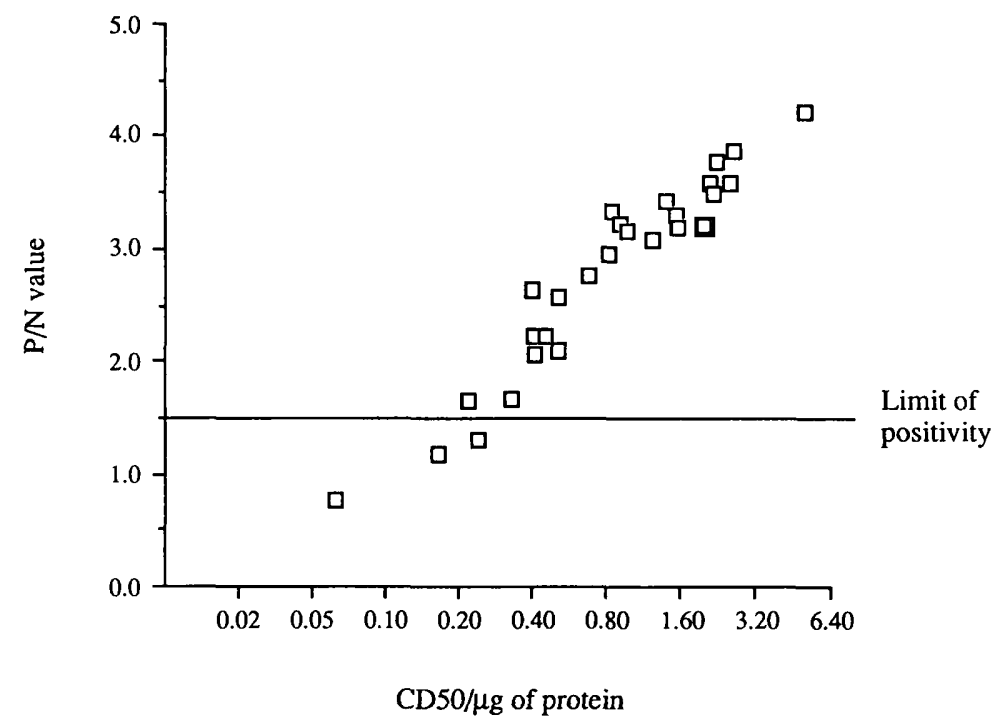

Fig. 4. Correlation between ELISA and the cytotoxicity assay with sonicated extracts of $\mathrm{CNF}^{+}$strains. Regression analysis gave a correlation of $r=0.98$.

The reproducibility was determined by testing the same extract (sonicated extract from the strain $\mathrm{BM} 2-1)$ in 12 different plates during a 2-month period. The mean of the $12 \mathrm{P} / \mathrm{N}$ values was 3.29 and the standard deviation was $0 \cdot 19$, i.e., $6 \%$.

\section{Applicability of ELISA to frozen-thawed extracts}

Frozen-thawed extracts were produced from a total of 122 strains, including $54 \mathrm{CNF}^{+}$strains (table I). The average total protein content of these extracts was 490 (SD250) $\mu \mathrm{g} / \mathrm{ml}$. The CNF activity, as measured in the cytotoxicity assay, was higher in frozen-thawed extracts than in sonicated extracts for 29 of the 30 strains that were tested with both types of extraction. Overall, there was a four-fold increase of specific activity in frozen-thawed extracts, but with large variations between strains. The three lowest producers of the preceding sample of strains (Pomd B, $7 \mathrm{~d}, 249$ ) contained 0.24, $0 \cdot 16$ and $0.06 \mathrm{CD} 50 / \mu \mathrm{g}$ of protein in sonicated extracts and $0.80,1.70$ and $0.70 / \mu \mathrm{g}$ of protein in frozenthawed extracts respectively.

Frozen-thawed extracts were tested undiluted in the ELISA (mean of $49 \mu \mathrm{g} /$ well). The non-specific background obtained with this type of extract was about the same as with sonicated extracts. The range of $\mathrm{P} / \mathrm{N}$ values for $\mathrm{CNF}^{-}$strains, shown in

Table II. Effect of sonicated bacterial extract concentration on ELISA result

\begin{tabular}{|c|c|c|c|}
\hline \multirow[b]{3}{*}{ Strain no. } & \multirow[b]{3}{*}{ Type of toxin (CD50/ $\mu \mathrm{g}$ of protein) } & \multicolumn{2}{|c|}{$\mathrm{P} / \mathrm{N}$ value* } \\
\hline & & \multicolumn{2}{|c|}{ (amount of protein/well) } \\
\hline & & $27 \mu \mathrm{g}$ & $108 \mu \mathrm{g}$ \\
\hline EB28 & CNF $(1 \cdot 570)$ & $3 \cdot 30$ & $2 \cdot 88$ \\
\hline BUV 21 & CNF $(0.840)$ & $3 \cdot 25$ & $2 \cdot 88$ \\
\hline Pomd B & CNF $(0 \cdot 240)$ & $1 \cdot 30$ & 1.73 \\
\hline $7 \mathrm{~d}$ & CNF $(0 \cdot 160)$ & $1 \cdot 18$ & 1.71 \\
\hline 249 & CNF $(0 \cdot 060)$ & 0.68 & 0.98 \\
\hline B20a & Vir cytotoxin & $1 \cdot 23$ & $1 \cdot 23$ \\
\hline S5 & Vir cytotoxin & $1 \cdot 21$ & 0.81 \\
\hline B24c & Vir cytotoxin & 1.08 & $1 \cdot 11$ \\
\hline B41 & ST & 0.96 & 0.99 \\
\hline
\end{tabular}

*Positive/negative $(\mathrm{P} / \mathrm{N})$ value : $\mathrm{OD}$ of the sample divided by $\mathrm{OD}$ of the $\mathrm{CNF}^{-}$mutant (BM2-1-M1). 


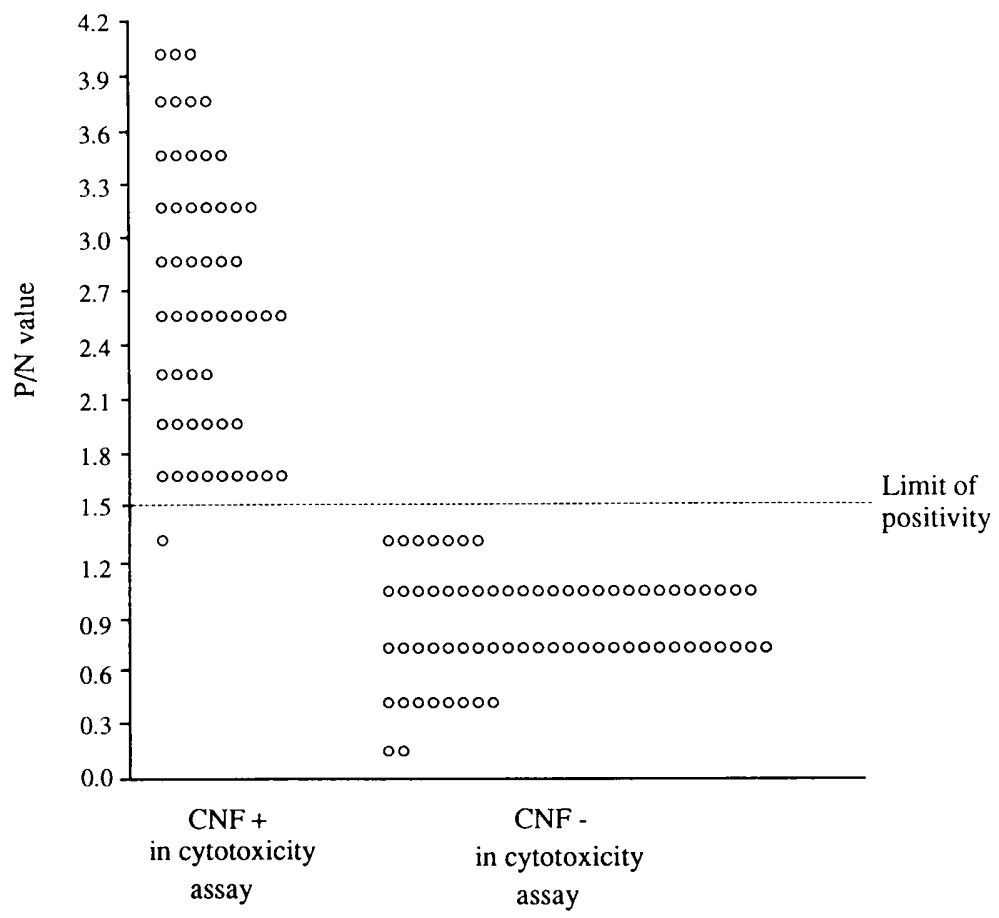

Fig. 5. ELISA results with frozen-thawed extracts (three cycles) of $54 \mathrm{CNF}^{+}$strains and $68 \mathrm{CNF}^{-}$strains with reference to cytotoxicity results in the HeLa cell culture assay.

fig. 5, fitted a normal distribution (test of goodness of fit; $5 \mathrm{df}$; $\mathrm{p}>0.05$ ). As with sonicated extracts, the minimum positive $P / N$ value was defined as the mean $\mathrm{P} / \mathrm{N}$ value of the 68 strains which were $\mathrm{CNF}^{-}$ in the cytotoxicity assay $(0.90)$ plus two standard deviations $(2 \times 029)$ i.e., 1.48 . With this criterion, 53 of the $54 \mathrm{CNF}^{+}$strains were positive in the ELISA, and all $68 \mathrm{CNF}^{-}$strains were negative. The single false negative response was due to the lowest CNF producer examined in the form of frozen-thawed extract (strain 2168/s), which contained about $0.60 \mathrm{CD} 50 / \mathrm{mg}$ of protein. None of the strains producing the Vir cytotoxin reached the positive level in the ELISA. However, the mean P/ $\mathrm{N}$ value for $\mathrm{Vir}$ strains $(1 \cdot 10 ; \mathrm{SD}=0 \cdot 18)$ was larger than the one for strains producing neither CNF nor Vir $(0.84 ; \mathrm{SD}=0.25)$ and this difference was significant $(t=3.55 ; 66 \mathrm{df}$; $p>0.01)$ As a result, the $\mathrm{DI}(+)$ and $\mathrm{DI}(-)$ in the ELISA with frozenthawed extracts were estimated to be $98 \%$ and $100 \%$ respectively.

\section{Discussion}

The ELISA described in this study was designed for the detection of CNF-producing strains of $E$. coli. Our results show that it adequately serves this purpose. Evaluating firstly its ability to detect CNF in sonicated extracts, we found no false positive reaction with $45 \mathrm{CNF}^{-}$strains and only three false negative reactions, these being in tests with the lowest CNF producers of our sample group. Sonicated extracts of the latter strains contained approximately 100 -fold less cytotoxic activity $(0.060$ $\mathrm{CD} 50 / \mu \mathrm{g}$ of protein) than the highest producers $(5.050 \mathrm{CD} 50 / \mu \mathrm{g})$. Moreover, by increasing the amount of extracts/well from $27 \mu \mathrm{g}$ to $108 \mu \mathrm{g}$ of total protein, we were able to enhance significantly the signal of the low CNF-producers whilst keeping that of the non-producers approximately constant. This adjustment resulted in an overall improvement in detectability, but it also slightly reduced the response of the high CNF-producers. As a consequence the distribution of $\mathrm{P} / \mathrm{N}$ values for $\mathrm{CNF}^{+}$ strains was narrower with $108 \mu \mathrm{g}$ than with $27 \mu \mathrm{g}$ (table II).

The manipulation of individual bacterial cultures necessary during ultrasonic disintegration might restrict the large-scale examination of strains for CNF. Frozen-thawed extracts do not require such individual manipulation. The ELISA proved to be fully adaptable to frozen-thawed extracts. With undiluted extracts prepared from 10-fold concentration $24 \mathrm{~h}$ cultures in TSB, we observed only one 
false negative reaction in $54 \mathrm{CNF}^{+}$strains; this occurred with the lowest producer in the sample group. The use of frozen-thawed extracts thus resulted in improved detection. This was due to the slightly higher specific activity of frozen-thawed extracts and not from a lowering of the limit of detection since the non-specific background was about the same with both types of extract.

Whichever type of extract was used, no false positive reactions were recorded among strains producing other types of toxin, namely haemolysin, verotoxin and enterotoxin. Since CNF is most of ten associated phenotypically with haemolysin production in $E$. coli strains, ${ }^{1,5,7}$ it was particularly important to ascertain the absence of a positive response in the ELISA with haemolytic strains that did not synthesise CNF. The result corroborates the distinction between the CNF and the haemolysin molecules previously suggested by the absence of co-purification of the two corresponding activities $^{1}$ and by the production of laboratory mutants lacking haemolytic activity but retaining full CNF production. ${ }^{3}$ The absence of a positive response by VT-producing strains was predictable from our previous observations that a rabbit antiserum against CNF (neutralising titre 256) was unable to neutralise the cytotoxic effect in Vero cell cultures of both VT1 ${ }^{7}$ and VT2 (unpublished data). These new data therefore confirm the absence of immunological relatedness between CNF and verotoxins on the one hand and between CNF and enterotoxins on the other.

In the same way, none of the strains producing the Vir cytotoxin induced a response above the

\section{REFERENCES}

1. Caprioli A, Falbo V, Roda L G, Ruggeri F M, Zona C. Partial purification and characterization of an Escherichia coli toxic factor that induces morphological cell alterations. Infect Immun 1983; 39: 1300-1306.

2. Caprioli A, Donelli G, Falbo L et al. A cell division-active protein from Escherichia coli. Biochem Biophys Res Commun 1984; 118 : 587-593.

3. De Rycke J, Phan-Thanh L, Bernard S. Immunochemical identification and biological characterization of cytotoxic necrotizing factor of Escherichia coli. J Clin Microbiol 1989; 27 : 983-988.

4. Caprioli A, Falbo V, Ruggeri F Met al. Cytotoxic necrotising factor production by hemolytic strains of Escherichia coli causing extra-intestinal infections. J Clin Microbiol 1987; 25 : 146-149.

5. Alonso P, Blanco J, Blanco M, González E A. Frequent production of toxins by Escherichia coli strains isolated from human urinary tract infections: relation with haemagglutination. FEMS Microbiol Lett 1987; 48: 391-396. minimum $P / N$ value, although the specific cytotoxic effect produced by these strains was partly neutralised by both rabbit and sheep IgG preparations. This observation implies that the ELISA described here is apparently strictly specific for CNF. However, the detailed analysis of data obtained with frozen-thawed extracts showed that the mean $P / N$ value of Vir strains $(1 \cdot 10)$, although unequivocally below the detection limit (1.48), was nonetheless significantly larger than the mean value of strains that produced neither CNF nor Vir (0.84). However the response by strains producing the Vir cytotoxin was too weak to permit the detection of Vir strains under the conditions of the assay.

In conclusion, the ELISA that we have devised is a reliable means of detecting $\mathrm{CNF}$ in lysates of $E$. coli isolates. Its applicability to frozen-thawed extracts will enable large numbers of strains to be examined because (a) no manipulation of individual bacterial cultures is necessary for lysate production, (b) small culture volumes can be used, and (c) no sterilisation of extracts is required. Compared to the cytotoxicity assay in HeLa cell cultures, this assay is simple, rapid, economic, and requires no elaborate equipment. It will facilitate a systematic examination of clinical isolates of $E$. coli for CNF and help to elucidate the association of CNFproducing strains with intestinal and extra-intestinal infections in man and animals.

We thank R. Bolvin for his technical assistance, S. Bernard, M. Pepin and B. Poutrel for their critical reading of the manuscript, and Julia Woodman for English corrections.
6. González E A, Blanco J. Production of cytotoxin VT in enteropathogenic and non-enteropathogenic Escherichia coli strains of porcine origin. FEMS Microbiol Lett 1985; 26 : 127-130.

7. De Rycke J, Guillot J F, Boivin R. Cytotoxins in nonenterotoxigenic strains of Escherichia coli isolated from feces of diarrheic calves. Vet Microbiol 1987; 15: 137150.

8. Blanco J, González E A, Garcia S, Blanco M, Regueiro B, Bernardez I. Production of toxins by Escherichia coli strains isolated from calves with diarrhoea in Galicia (North-western Spain). Vet Microbiol 1988; 18: 297311.

9. McLaren I, Wray C. Another animal Escherichia coli cytopathic factor. Vet Rec 1986; 119: 576-577.

10. Smith H W. A search for transmissible pathogenic characters in invasive strains of Escherichia coli: the discovery of a plasmid-mediated toxin and a plasmid-controlled lethal character closely associated, or identical, with colicine V. J Gen Microbiol 1974; 83: 95-111.

11. Oswald E, De Rycke J, Guillot J F, Boivin R. Cytotoxic 
effect of multinucleation in HeLa cell cultures associated with the presence of Vir plasmid in Escherichia coli strains. FEMS Microbiol Lett 1989; 58: 95-100.

12. Bradford $M$ M. A rapid and sensitive method for the quantification of microgram quantities of protein utilizing the principle of protein-dye binding. Anal Biochem 1976; 72 : 248-254.

13. McKinney M M, Parkinson A. A simple, non-chromatographic procedure to purify immunoglobulins from serum and ascites fluid. $J$ Immunol Methods 1987; 96: 271-278.

14. Guesdon J L, Avrameas S. Polyacrylamide-agarose beads for the preparation of effective immunoadsorbents. $J$ Immunol Methods 1976; 11 : 129-133.

15. Tijssen P. Enzyme Immunoassays. In: Richard B, Kohler M D (eds) Antigen detection to diagnose bacterial infections, vol. 1, Methodology. Boca Raton, CRC Press. 1986: 99-135. 